\title{
Feeding soils: nutrient balance in the northeast of the Iberian Peninsula c. 1920
}

\author{
Elena Galán del Castillo
}

KEYWORDS: social metabolism, socio-ecological transition, regional nutrients balance, agricultural change.

JEL CODES: N53, N93, Q10, Q19.

$U$

nderstanding the replacement of soil nutrients removed by harvests provides insight into human influence on land fertility. The nitrogen $(N)$, phosphorus $(P)$ and potassium $(K)$ content of cropland in the province of Barcelona circa 1920 was examined with the aim of improving the methodology from a previous study of cropland nutrient balance circa 1860 in a municipality located in the same province. The main fertilization differences between the two studies involve the use of more manure per hectare circa 1920 and the occurrence of more $N$ fixation due to leguminous crops. Though slightly negative for $K$, the data generally exhibited a nutrient inputlextraction balance. Also noteworthy is the fact that by the latter date synthetic fertilizers had become available. The methodological limitations that constrain a full comparison of the results of the two studies have been provided. Finally, although we could not disaggregate the data on fertilizer per crop type, the results lead us to consider the relationship between fertility and inequality. 


\title{
Alimentando suelos: balances de nutrientes en el noreste de la península Ibérica circa 1920
}

\section{PALABRAS CLAVE: metabolismo social, transición socioecológica, balance regional de nutrientes, cambio agrario.}

\section{CÓDIGOS JEL: N53, N93, Q10, Q19.}

\begin{abstract}
C mprender la sustitución de los nutrientes extraídos por las cosechas nos ayuda a entender la influencia de los seres humanos sobre la fertilidad. Hemos hecho un balance de N, P y Ken tierras de cultivo de alrededor de 1920 de la provincia de Barcelona. El objetivo era mejorar la metodología de un estudio previo sobre el equilibrio de nutrientes de la superficie de tierra agrícola en un municipio situado en la provincia de Barcelona alrededor de 1860. También se han incluido las limitaciones metodológicas que restringen la comparación de los resultados de ambos estudios. La principal diferencia en cuanto a fertilización entre los dos balances es que aproximadamente en 1920 aparecen los fertilizantes sintéticos y, además, hay más estiércol por hectárea y más fijación de $N$ a través de las leguminosas sembradas que alrededor de 1860. El balance global indica que las extracciones de nutrientes estaban en equilibrio con las adiciones, aunque el balance es ligeramente negativo para el K. Por último, aunque no pudimos desagregar las entradas de fertilizante por tipo de cultivo, los resultados nos llevan a considerar la relación entre la fertilidad y la desigualdad.
\end{abstract}

\section{Premio Historia Agraria 2014}

Este artículo obtuvo el IX Premio de Historia Agraria a trabajos realizados por jóvenes investigadores referidos a la historia agraria, la economía y la sociedad rurales, desde una perspectiva interdisciplinar.

Received: 2015-03-19 • Revised: 2016-10-12 - Accepted: 2016-10-17.

Elena Galán del Castillo is a Post-doctoral Researcher and is currently working at Basque Centre for Climate change. Adress: Basque Centre for Climate Change, Building 1, $1^{\text {st }}$ floor, Scientific Campus of the University of the Basque Country, 48940 Leioa (Bizkaia,Spain).E-mail:elena.galan@bc3research.org 


\section{INTRODUCTION: NUTRIENT FLOWS, HISTORY AND AGRICULTURAL SYSTEMS}

Accounting for the flows of nutrients within a system nowadays allows assessing the impact of waste related to human activities in the environment. For example, Kimura and Hatano (2007), and Kimura, Liang and Hatano (2004) assessed the increasing N pollution in the agricultural system of the city of Hokkaido (Japan) due to the separation of consumption and production food sectors during the twentieth century. Lassaletta et al. (2013) analysed the increase of $\mathrm{N}$ emissions within Spanish river basins due to the change in diet patterns from 1960 to 1990. Billen et al. (2007a) explored the changing relationship between the population of Paris and the Seine River over 500 years through the quantification of N, P and Si flows.

However, when applied to prior periods, the analysis of nutrients flows has given information about the relation between harvests and the management practices to add nutrients to soils. The studies of the impacts of rotations including legumes (specially the Norfolk rotation) and convertible husbandry in England and Northern Europe until they reached productivity ceilings are well known examples (Allen, 2008; Chorley, 1981). The study of Tello et al. (2012) attempted to do a similar study for the Northeast of the Mediterranean Iberian Peninsula taking as a case of study the municipality of Sentmenat circa 1860. Due to lack of data, they could not follow the nutrient flows in other (more arid) municipalities, crop type or rotation or extend the analysis in time. They concluded that, probably, to balance the soil nutrients of some crop types, others such as vineyards had to be short of nutrients. We aim to expand that study by doing another case circa 1920 to assess the evolution of the importance of organic and synthetic fertilizers for the maintenance of fertility.

The case circa 1920 should be interesting because the area had just recovered the share of vineyard land ( $50 \%$ of the cropland area) of 1860 , which was destroyed at the end of the century by the Phylloxera plague. After the outbreak, the grape growers increased the yield of the crop, mainly through the increase in manuring and the use of chemical fertilisers (Badia-Miró et al., 2010).

The changes of Barcelona city between 1860 and 1920 (the medieval walls were demolished and the city expanded annexing the nearby municipalities) had strong implications to the fertility of the surrounding areas as well. During this period, it was the second city in Spain in number of inhabitants $(710,335)$ very close to the 750,896 of the capital Madrid (INE, 1920). This involved a high potential as a producer of organic material but overall a high -and growing- demand of agricultural produce from the sur- 
rounding areas. It was one of the first ones in the Mediterranean making a systematic use of fossil fuels (importing mineral coal) for industrial and urban uses (Sudrià, 1987) which also could influence the availability of organic matter in the area. Finally, the area of Barcelona was involved in the First Globalisation through international trade (e.g. coal and raw cotton imports and wine exports). That could expand the use of synthetic synthetic fertilisers throughout the area, although not $\mathrm{N}$ because the Haber-Bosch process did not spread globally until the end of Second World War (Smil, 2001).

\section{FIGURE 1}

Location of the study area: the municipality of Sentmenat and neighbouring townships in the province of Barcelona and Catalonia (Spain)

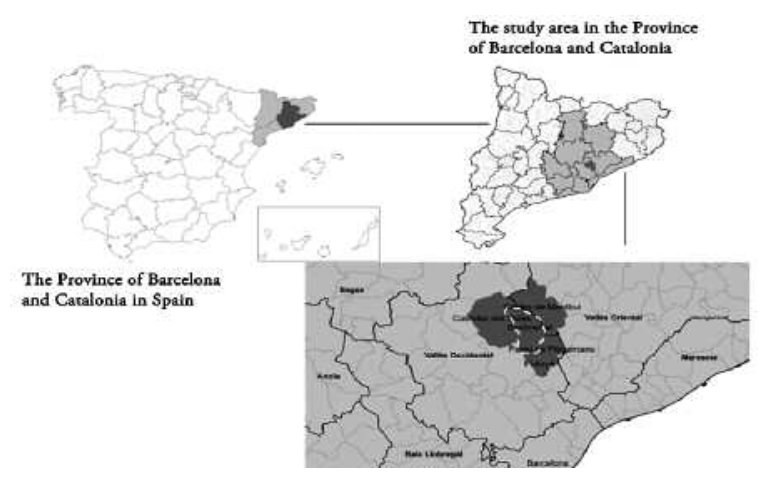

Source: Marull, Pino and Tello (2008).

Comparing the nutrient balance of the same case study at the beginning of the twentieth century would be very interesting in order to analyze the transition towards an industrial mode of agriculture. However, the limited availability of sources will constraint the analysis and compromise the interpretation of the results. Nevertheless, the analysis of sources and surpassing obstacles to reconstruct the nutrient flows of past agricultural systems is a result by itself: [...] even admitting a margin of error, which can only be reduced through future calibration and comparison with other balances, we believe that the usefulness of this assessment lies in its heuristic function (Tello et al., 2012: 376).

\section{MATERIAL AND METHODS}

\subsection{Scale justification and limitations}

For the analysis $c$. 1920, we used the data at the only available scale, the province, whereas Tello et al. (2012) used municipal scale. These differences on scale are the result of the historical processes that created the available sources. 
During the nineteenth century, the configuration of the Spanish liberal State and a centralized tax office gave rise to the consolidation of a new and unified Spanish fiscal system. From then, not only a number of cadastral surveys and statistical information of the mid-nineteenth century are available as historical sources. Additionally, as a reaction to the new taxes on land, some towns and villages all over the Spanish State declared land by providing detailed information about land properties, in the form of reports, maps, etc. However, opposite as the consolidation of other liberal states such as France or the Austro-Hungarian Empire, this process was done in a chaotic way and the information that remains today is far from centralized, complete and homogeneous. From 1860s onwards the main source for calculation of the State agricultural taxes were the amillaramientos surveys about rural properties and its monetary value, which is the main source that we used for these years (Muro, Nadal \& Urteaga, 1996).

At first, these amillaramientos were conceived as a temporary expedient until the Spanish cadastre ended, but as this eventually did not happen in the nineteenth century, they remained in a fossilized state. From the beginning of the twentieth century and until the end of that monarchic regime with the Second Spanish Republic, they became increasingly out of date. As a result, the tax system deteriorated and became more and more conflictive, which also entailed the deterioration of the amillaramientos as a reliable historical source.

Hence, the amillaramientos have some disadvantages as a statistical source. First, as they were a fiscal instrument, some information could have been omitted or distorted to avoid the payment of higher taxes. Second, the information is rather general, they offer mainly total areas of irrigated and rainfed land classified by the main agricultural uses (grains, vines, olive orchards and other arboriculture crops, pastureland and woodland) without specifying rotations and fallow land. To turn this basic information on land uses into taxable incomes some converters, such as average yields, current prices of products and usual cost of the main inputs (labour, draught power, seeds, manure, etc.) were required. This information was provided by the cartillas evaluatorias, a crucial document only rarely kept in local archives -thus obliging us to resort to the few that are available which do not always correspond to the particular local conditions of the area studied. Third, once the land of a municipal territory had been classified in the first amillaramiento, only the final distribution of the tax burden according to the taxable incomes assigned were updated over time. This does not provide enough periodicity to make a real series (GEHR, 1991). Last, but not least, the information on land uses was only kept at municipal level and no aggregated statistics was compiled at district, provincial or national level throughout this period. 
In 1879, the Ministerio de Fomento established the Servicio Agronómico de España to centralize the surveys dealing with the agricultural sector. It was organized by the chief agronomist engineers of each province and a higher level of nine engineers located in the capital, which were known as the Junta Consultiva Agronómica, which published some reports until the reform of 1927, when a series of agricultural yearbooks started (GEHR, 1991). Notwithstanding, the information that they generated in the first decades of its existence was incomplete and poorly detailed, and the local surveys that the engineers of each province used to compile in the provincial reports during all the lifespan of the Junta Consultiva Agronómica have never been found (GEHR, 1991).

Summing up, for the years $1845-65$ we have a number of local sources, but it is almost impossible to find and group them to allow the aggregation at provincial scale or even other smaller administrative units such as the comarcas (similar to English counties). Then, from the 1860 s to the 1890 s there is an authentic statistical blackout, created not only by what has been explained above but due to the tumultuous period of the Sexenio Revolucionario (1868-73) and the Third Carlista War (1872-76), followed by a lack of interest to renew the fiscal system in the first decades of the Restauración Borbónica (1874-1931). It was only after 1890 , when the idea that the State had to become an active stakeholder in the economic improvement of the country, that we start to have a proliferation of aggregated statistical sources, by Province and sometimes by partido judicial (similar to English districts), but not local districts. As a result, from 1845 to 1865 we can carry out many local case studies but there are not historical series at provincial and national level. Ironically, after the statistical blackout from 1860 to 1890, we can start relying on the series and surveys compiled by the Junta Consultiva Agronómica (JCA) at provincial or national level, but no local information is available.

Tello et al. (2012) selected Sentmenat (Figure 1) as a local case study for two main reasons, the availability of sources and the long trajectory of research on these sources. The aristocrat lineage of the Marquises of Sentmenat had carefully preserved their patrimonial documents over the centuries, and they finally donated it to the main archive of Catalonia, the Arxiu de la Corona d'Aragó. The richness and detail of these records allowed a number of studies. As the feudal and landlord bookkeeping together with copies of probate inventories and wills contained a great deal of information about land uses, crop yields, water conflicts, rents, tithes, wages, litigations, etc. (Badia-Miró \& Tello, 2014; Cussó, Garrabou \& Tello, 2006; Garrabou et al., 2001, 2010; Millán, Tello \& Jover, 2006; Serra, 1988; Soto \& Batet, 1997). 


\subsection{Characteristics of the study site and limitations of the sources}

We cannot compare the evolution of land uses due to scale differences. In addition, the category "Improductive" c. 1860 includes land uses that c.1920 are considered as part of the category "Forest". However, we have included the land uses from Tello et al. (2012) to provide basic information of their case study $c .1860$.

\section{TABLE 1}

Main characteristics of the municipality of Sentmenat and the province of Barcelona

\begin{tabular}{|c|c|c|}
\hline c. 1860 & entmenat & c. 1920 Barcelona province \\
\hline \multicolumn{3}{|c|}{$\%$ total area } \\
\hline Forest & 25.1 & 56.9 \\
\hline Improductive & 15.6 & 5.6 \\
\hline Cropland & 59.3 & 37.5 \\
\hline \multicolumn{3}{|c|}{$\%$ cropland area } \\
\hline Cereal and leguminous rainfed & 13.2 & 26.5 \\
\hline Cereal and leguminous irrigated & 5.7 & 5.4 \\
\hline Roots and bulbs & & 4.1 \\
\hline Horticultural land & 0.9 & 3.2 \\
\hline Industrial & & 0.1 \\
\hline Forages & 8.0 & 3.2 \\
\hline Olive and fruit trees & 7.5 & 5.2 \\
\hline Vineyard & 64.7 & 52.4 \\
\hline Population density (inhab/km²) & 59 & $176\left(61^{\star}\right)$ \\
\hline Livestock density per cropland area (LU 500 kg/km²) & 12 & $40\left(8^{\star \star}\right)$ \\
\hline
\end{tabular}

${ }^{\star}$ For the municipality of Sentmenat.

${ }^{\star \star}$ For the partido judicial of Sabadell, to which Sentmenat belongs for the census of 1917.

Source: Tello et al. (2012) and INE (1920), MF (1924), JCA (1920, 1923).

In the province of Barcelona the share of forest land was higher than the $10-15 \%$ that was observed for the most of Spain by the geographer Huguet del Villar in 1921 (Tello \& Sudrià, 2011). The half of the cropland was occupied by vineyards, although they were not as the pre-Phylloxera vines of the ninetieth century. To overcome the plague, European varieties of had to be grafted into American rootstocks and protected from the diseases that accompanied them such as the mildiu or downey mildew (Plasmopara viticola) (Piqueras, 2005). Some farmers also started to fertilise them (recall that the pre-phylloxera vines were not fertilized). As a result this new viticulture needed more labour than before, up to 94 man-equivalent working days per year per hectare, vis-à-vis the 25 needed in extensive cultivation of cereals with fallow that was practiced in inland Spain and the 
province of Lleida (Badia-Miró et al., 2010). The second largest crop was rainfed cereal and leguminous crops.

In Sentmenat, population densities were similar in the two periods. However, the high population and livestock densities of the province of Barcelona are due to the influence of Barcelona city, which was the second city in Spain in number of inhabitants, just after the capital Madrid (INE, 1920). As happened with other cities such as Paris (Barles, 2007; Billen et al., 2007b), it was more likely that the cropland areas surrounding Barcelona took advantage of dumping from these high population and livestock densities. However, although we can disaggregate the population densities to municipal scale and livestock to partido judicial, crop type areas are only at province scale. Therefore, to aggregate the analysis at the provincial scale, we are assuming that the fertilizers were distributed equally. In order to interpret the balance though, we will take into account that for areas distant from Barcelona it was probably more negative.

Other effects that cannot be discriminated in the provincial balance are the differences of yields between regions. We know that the yields of cereals in Sentmenat area could have been lower than in other places of the province of Barcelona such as Osona (Garrabou et al., 1995). Moreover, the sources show two moments of time because the annual variability could lead us towards uncertain conclusions (cartillas evaluatorias used to be fiveyear compilations and the report from Junta Consultiva Agronómica only related to one year). In addition, we had to use the same sources in both years for nutrient content, therefore we cannot specify nutrient variations in the composition of ancient crop types and cultivars due to lack of reliable information.

Summing up, what is left for comparison between 1860 and 1920 due to scale mismatch is: a) the type of fertilizer; b) the composition of harvest; and c) the relation between what is extracted and what is added, i.e. the nutrient balance.

\subsection{Methodology of NPK balances in historical farm systems}

A nutrients balance or budget is to account for the nutrient flows of a system. The flows considered will vary depending on the conceptualization of the system. The system boundaries (e.g. cropland soil, farm gate, etc.) and the scale (e.g. farm, with or without livestock, regional, national, etc.) vary depending on the purpose of the analysis (Oenema, Kros \& De Vries, 2003). 
Figure 2 shows the flows distinguished in the present study and Table 7 details the sources to quantify these flows. We followed the "Guidelines for Constructing Nitrogen, Phosphorus, and Potassium Balances in Historical Agricultural Systems" (Garcia-Ruiz et al., 2012; González de Molina, 2010) for the present study. We do not want to repeat here the methodology that is published elsewhere. In this section, we explain the methodological details to calculate flows of manure and humanure ${ }^{1}$ and the losses of $\mathrm{N}$ through nitrification, volatilization and leaching to adapt them to our data. We also included the methodological differences between the balance $c .1860$ and c. 1920 and its implications.

FIGURE 2

Scheme of the nutrient flows considered

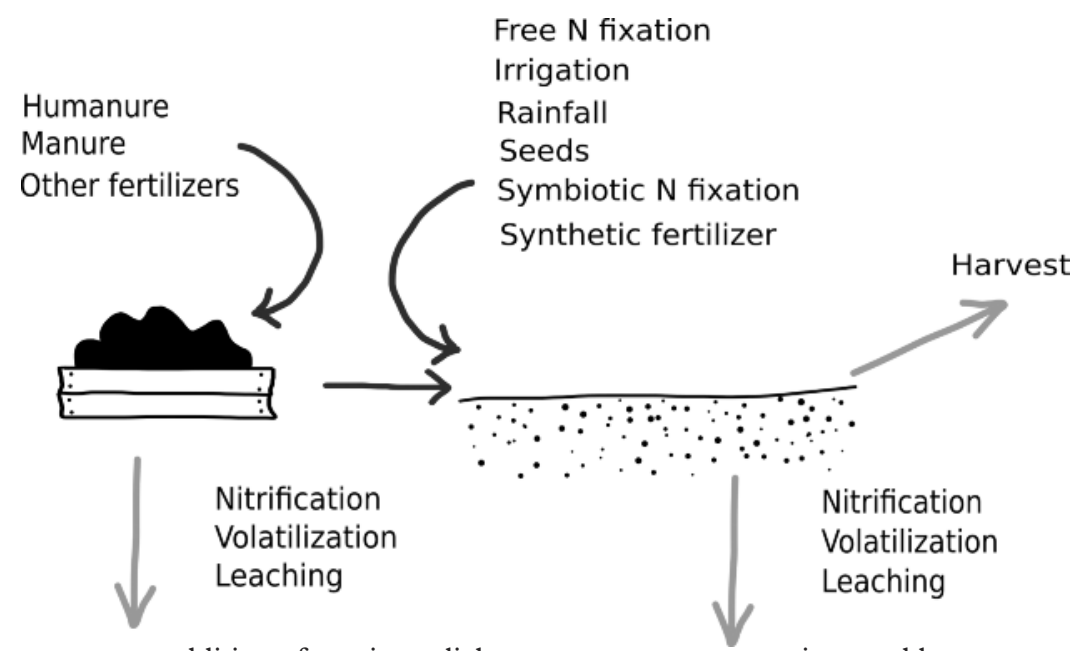

Dark arrows represent addition of nutrients, light grey arrows are extractions and losses.

Source: own elaboration.

\subsubsection{Differences from manure estimation}

García-Ruiz et al. (2012) had the data of carts of manure used and the application rates on fields. However, this information was not available for our area even though the existence of the report Materias fertilizantes empleadas en la agricultura (JCA, 1921), where provincial engineers of the Spanish state quantified the amount of any kind of material applied to agricultural soils in 1919. There, the engineers quantified the amount of manure applied to fields by estimating the manure available per province, but they did not

1. We preferred to use this elegant way when referring to human fecal material and urine and its potential as fertilizer (JENKINS, 2005) as started to be used in scientific journals e.g. SCHNEIDER and MCMiCHAEL (2010) instead of a large and confusing list of euphemisms. 
indicate how they made the estimations. In addition, the numbers for manure in Barcelona province are not coherent throughout the text. Moreover, they estimated that approximately $40 \%$ of the cropland of the entire province was not fertilized, but as they did not specify the unfertilized area per crop type, the application rates of fertilizers per crop type that they provide are useless for us for this purpose. For these reasons, we decided to calculate the availability of manure using the nearest livestock census (Table 7) and not to disaggregate the balance per crop types.

García-Ruiz et al. (2012) indicate that as sheep and goat did not use to be penned at night it is reasonable to assume that only one third of the manure produced was available. However, we did not apply this because we used the manure production data from Cascón (1918), who only reported the manure collected in barns, but not the manure that remained in pastures.

We increased the number of sources for manure and humanure production (Table 2) and composition (Table 3) than those used in Tello et al. (2012). Two main concerns motivated this change: the huge potential variability of data (as production and composition of manure relies on a number of factors such as diet, age, activity, etc.) and the lack of dry weight data. We included Standard Deviations for manure and humanure to leave some space for variability and thus increasing the robustness of the analysis.

TABLE 2

\begin{tabular}{|c|c|}
\hline \multicolumn{2}{|c|}{ 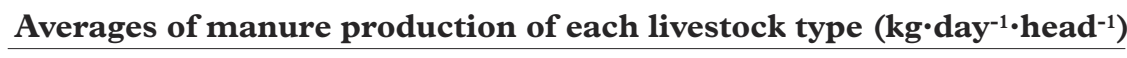 } \\
\hline \multicolumn{2}{|c|}{ Livestock type $\quad$ Manure $\left(\mathrm{kg}^{\left.- \text {day }^{-1} \cdot \text { head }^{-1}\right)}\right.$} \\
\hline Cows and oxen & $27.4 \pm 7.3$ \\
\hline Horses & $20.1 \pm 4.9$ \\
\hline Mules & $17.3 \pm 3.7$ \\
\hline Donkeys & $8.9 \pm 2.4$ \\
\hline Sheep & $1.9 \pm 1.1$ \\
\hline Goats & $1.6 \pm 1.1$ \\
\hline Swine & $7.0 \pm 2.8$ \\
\hline
\end{tabular}

Source: see Table 7 .

The average for all livestock types together were coherent with the ones that Gotaas (1956) reported as average for stable manure at fresh state: $70-80 \%$ moisture, $0.3-1.9 \% \mathrm{~N}, 0.1-$ $0.6 \% \mathrm{P} 2 \mathrm{O} 5$ and $0.3-1.2 \%$ of $\mathrm{K} 2 \mathrm{O}$. Also, with those adopted by Gallego (1986) $0.62 \%$ $\mathrm{N}, 0.27 \% \mathrm{P} 2 \mathrm{O} 5$ and $0.63 \%$ of $\mathrm{K} 2 \mathrm{O}$. 


\section{TABLE 3}

Average values of nutrient composition of manure (\% of fresh weight)

\begin{tabular}{lcccc}
\hline Average manure type & $\mathbf{N}(\%$ fresh weight) & $\mathbf{P}(\%$ fresh weight) & $\mathbf{K}(\%$ fresh weight) & Water (\%) \\
\hline Cows and oxen & $0.60 \pm 0.25$ & $0.13 \pm 0.06$ & $0.53 \pm 0.43$ & $72.91 \pm 14.00$ \\
Horses and other from horse family & $0.60 \pm 0.05$ & $0.12 \pm 0.01$ & $0.46 \pm 0.12$ & $70.25 \pm 7.09$ \\
Sheep and goat & $0.89 \pm 0.18$ & $0.16 \pm 0.08$ & $0.46 \pm 0.10$ & $64.33 \pm 4.04$ \\
Swine & $0.52 \pm 0.08$ & $0.15 \pm 0.05$ & $0.38 \pm 0.10$ & $80.17 \pm 5.78$ \\
\hline
\end{tabular}

Source: Galán (2015: Annex 4.B).

\subsubsection{Differences from humanure estimation}

A number of sources recognise the use of human faeces at some degree of composting from human settlements where cesspits were used for disposal of human faeces. This was a common situation of Catalan villages, even for cities like Barcelona that $c .1920$ still was waiting for the renewal of their sewage system as the one proposed by García Faria (1893). When discussing the awareness of farmers to replenish nutrients from soil, Cascón (1918), from his experimental farm in Palencia, praises Catalan farmers because there were known to use human faeces as fertilizer. JCA (1921) gives details -but does not quantify $^{2}$ - about how cesspits from Barcelona were emptied and then how human faeces were treated and transported to be sold to the farmers of the surrounding coastal horticultural lands to cultivate vegetables that were eventually sold to Barcelona. This kind of nutrients recirculation from city to fields has also been reported by several cases also at the beginning of the twentieth century (Billen et al., 2007a, 2007b; Ellis \& Wang, 1997; Kimura, Liang \& Hatano, 2004; Kimura \& Hatano, 2007). It even was recommended by engineers of the beginning of the twentieth century such as King (1911) or the Spanish García Faria (1893).

In the first half of the twentieth century in Catalonia, there were broadly three types of human settlement: disseminated rural houses or group of houses (population that inhabits in 10 buildings or less is accounted as "disseminated" by Nomenclator), concentrated rural villages and urban areas (Esteve, 2003). To estimate the humanure available for agriculture, we associated the potential collection of faeces through three disposal systems typical of each settlement type. Disseminated rural settlements used manure heaps. Concentrated rural villagers used cesspits, which were sealed or were emptied from time

2. Also, a recurrent problem when trying to collect statistical information about the application of human faeces is the ambiguity of naming them, usually referred as abonos flamencos, letrinas or fenta, and although they were specific forms of preparation of human faeces, e.g. poudrette or Abonos Lucas (LLORENTE \& GALÁN, 1910), the agronomists in charge of the statistics use them equally. 
to time by farmers. Finally, urban populations had a mixture of cesspits and insufficient sewage systems that released human waste directly to water bodies.

The report from García Faria (1893), quantified Manchester waste flows as one third going to the river, one third released by the sewage system to fields and one third collected, treated and sold. As our biggest urban area is Barcelona city, we assumed two thirds released to the sea, one third storaged in cesspits and so potentially collected. To differentiate between rural and urban we followed the criteria of the Spanish Instituto Nacional de Estadística, which considers as urban the settlements with a population higher than 2000 inhabitants. We did not account for urine due to the difficulties to collect it and the high losses due to ammonia volatilization.

Once these assumptions are accepted, the difficulties were the same like those for animal manure. Production of human faeces is between $135-270 \mathrm{~g} \cdot$ day $^{-1} \cdot \mathrm{cap}^{-1}$ fresh weight without urine (Gotaas, 1956). According to the number of inhabitants per settlement (Esteve, 2003), the average of potentially collected human faeces was $37.8 \pm 12.3 \mathrm{kt}$. Table 4 shows the NPK composition of humanure.

\section{TABLE 4}

Average values of nutrient composition of humanure

\begin{tabular}{ccccc}
\hline & $\mathbf{N}(\%)$ & $\mathbf{P}(\%)$ & $\mathbf{K}(\%)$ & Water (\%) \\
\hline Average & $1.02 \pm 0.66$ & $0.28 \pm 0.26$ & $0.32 \pm 0.21$ & $75 \pm 8$ \\
\hline
\end{tabular}

Source: Galán (2015: Annex 4.B).

\subsubsection{Differences from NPK losses}

The next important difference from García-Ruiz et al. (2012) concerned the emission of nutrients to the atmosphere or water bodies. We could not find historical sources for the losses of N, P and $\mathrm{K}$, although for the analysis $c .1860$ were presumably found in Cascón (1918). However, this engineer only mentioned some experiments of $\mathrm{N}$ losses in manure in other countries and did not quantify nutrient losses on his farm, at least in the work cited, so we found an alternative way to quantify nutrient losses.

The Guidelines of the Intergovernmental Panel on Climate Change (Eggleston et al., 2006) quantified the $\mathrm{N}$ emissions linked to agriculture as nitrous oxide $(\mathrm{N} 2 \mathrm{O})$ is a greenhouse gas. Given that not all the $\mathrm{N}$ emissions are directly in the form of N2O, IPCC (Ibid., 2006) also accounts for other forms of $\mathrm{N}$ such as ammonia (NH3) or nitrates (NO) and nitrites (NO), which eventually can end in $\mathrm{N} 2 \mathrm{O}$ through reduction or oxidation. $\mathrm{NH} 3$ emissions are through volatilization, $\mathrm{NO}$ and $\mathrm{NO}$ through leaching. Nitrification is the 
aerobic microbial oxidation of ammonium $(\mathrm{NH})$ to nitrate and denitrification is the anaerobic microbial reduction of nitrate to nitrogen gas (N2), both processes produce naturally $\mathrm{N} 2 \mathrm{O}$.

$\mathrm{N}$ emissions in agriculture follow two processes: through storage, which involved almost $50 \%$ of the $\mathrm{N}$ in manure; and through management of agricultural soils, which included other fertilizers, tillage and irrigation. To calculate the losses during storage we needed to separate dung from straw (as the main losses occur in dung). Therefore, we estimated the amount of straw used and its composition correcting the amount of straw used per livestock type from Cascón (1918) with the available straw (JCA, 1923) and the NPK values for crop type by Soroa (1953). These considerations apply to humanure as well. The remaining details of the application of the IPCC guidelines to the Catalan case study are detailed in an extended way in Galán (2015: 116-25).

Using the methodology of IPCC (Eggleston et al., 2006) to calculate the $\mathrm{N}$ losses gives more robustness to the balance $c .1920$ than to $c .1860$. We revised the numbers of Tello et al. (2012) and we concluded that although the specific fluxes would have been quantitatively different, $\mathrm{N}$ coincides with the $\mathrm{N}$ losses calculated through IPCC (Eggleston $e t$ $a l ., 2006)$, which is approximately $50 \%$. The values for $\mathrm{P}$ losses are very low and barely affect to $2 \%$ of the total $\mathrm{P}$ losses. The values for $\mathrm{K}$ losses are overestimated and account for $13 \%$ of the total $\mathrm{K}$ losses.

Tello et al. (2012) also overestimated the losses from lixiviation. Considering a Mediterranean climate, they should have multiplied the lixiviation factor only by the irrigated land and not by all cropland area, and hence their value would drop from 5.5 to $0.23 \mathrm{~kg}$ of $\mathrm{N} \cdot \mathrm{ha}^{-1}$. Besides, they underestimated the losses from denitrification of managed land, which corrected using the methodology from IPCC (Eggleston et al., 2006) would have rose from 1.5 to $6.5 \mathrm{~kg}$ of N$\cdot \mathrm{ha}^{-1}$ approximately. However, the overall balance for $\mathrm{N}$ would not have significantly changed as they did not include $\mathrm{N}$ additions due to irrigation.

Something similar would have happened with $\mathrm{K}$ losses. Tello et al. (2012) calculated losses due to natural processes of $1.3 \mathrm{~kg} \cdot \mathrm{ha}^{-1}$, which accounted for $8.9 \%$ of the total $\mathrm{K}$ inputs. However, c. 1920 we did not take into account $\mathrm{K}$ losses because in Mediterranean climates would be negligible (Garcia-Ruiz et al., 2012). Hence, as K losses were overestimated when comparing the overall balance we have to consider that $\mathrm{K}$ inputs $c .1860$ should be $4.1 \%$ higher. 


\subsubsection{Differences from rainfall (deposition) and irrigation}

We did not follow the same methodology than Tello et al. (2012) for deposition and irrigation. The reason is that they took a value from a model for deposition from Holland $e t$ al. (1999) and did not account for NPK flows though irrigation. By doing so, they did not follow García-Ruiz et al. (2012), but this is because they could not find the appropriate sources. The steps that we followed to include them for the study $c .1920$ were the following.

For deposition, we looked for values from a low-polluted area. Probably, the best wellknown sampling site for ecology scientists in Catalonia is La Castanya valley in Barcelona province. Rodrigo (1998) measured wet deposition of $\mathrm{N}_{-} \mathrm{NO}_{3}, \mathrm{~N}_{-} \mathrm{NH}_{4}^{+}, \mathrm{P}_{-} \mathrm{PO}_{3}^{4}$ and $\mathrm{K}^{+}$as $27.9( \pm 2.3), 31.9( \pm 3.4), 1.03( \pm 0.12)$ and $3.45( \pm 0.42) \mu \mathrm{eq} / \mathrm{L}$ along a year $(1995-96)$. These values, corrected by the average precipitation of Barcelona province are in Table 5. Values of $\mathrm{N}$ were still higher than the ones of Garcia-Ruiz et al. (2012), whereas $\mathrm{P}$ and $\mathrm{K}$ were lower. We found even lower values in Holland et al. (1999), who attribute a preindustrial $\mathrm{N}$ deposition levels of $0.43 \mathrm{~kg} \cdot \mathrm{ha}^{-1} \cdot \mathrm{y}^{-1}(0.07-0.60)$ and $0.67 \mathrm{~kg} \cdot \mathrm{ha}^{-1} \cdot \mathrm{y}^{-1}(0.19$ 1.12) to Mediterranean scrubland and xenomorphic forest/woodland respectively. The latter were the values used in the previous chapter by Tello et al. (2012). However, Holland et al. (1999) did not take into account pre-industrial cropland areas but only natural vegetation, which could explain why their values are so low. Lacking of other criteria, we used data from Table 5 .

TABLE 5

Average wet deposition corrected by precipitation averages (1971-2000)

\begin{tabular}{lccccc}
\hline & $\begin{array}{c}\mathrm{N}-\mathrm{NO}_{3}^{-} \\
\left(\mathbf{k g} \cdot \mathbf{h a}^{-1}\right)\end{array}$ & $\begin{array}{c}\mathrm{N}-\mathrm{NH}_{4}^{+} \\
\left.\mathbf{( k g} \cdot \mathbf{h a}^{-1}\right)\end{array}$ & $\begin{array}{c}\mathbf{P}^{-} \mathbf{P O}_{4}^{3-} \\
\left.\mathbf{( k g} \cdot \mathbf{h a}^{-1}\right)\end{array}$ & $\begin{array}{c}\mathbf{K}^{+} \\
\left(\mathbf{k g} \cdot \mathbf{h a}^{-1}\right)\end{array}$ & $\begin{array}{c}\text { Precipitation Average } \\
(\mathbf{1 9 7 1 - 2 0 0 0 )} \mathbf{( m m})\end{array}$ \\
\hline Barcelona & 2.36 & 2.68 & 0.12 & 0.86 & 640 \\
\hline
\end{tabular}

Source: Rodrigo (1998) and AEMET.

Contributions of nutrients dissolved in water for irrigation could be approximated by concentrations in current unpolluted streams nearby the study case (Garcia-Ruiz et al., 2012). Lacking data of unpolluted streams, we collected 10 years average data from fountains in unpolluted areas of each province from $\mathrm{ACA}^{3}$ online database (Table 6). The values were similar to those considered in Garcia-Ruiz et al. (2012) $2.0,0.05$ and $2.0 \mathrm{mg} \cdot \mathrm{L}^{-1}$ of $\mathrm{N}, \mathrm{P}$ and $\mathrm{K}$.

3. Agència Catalana de l'Aigua is a public entity considered the hydraulic authority in Catalonia. 


\section{TABLE 6}

NPK content of water for irrigation in Barcelona province $c .1920$

\begin{tabular}{lcc}
\hline $\mathbf{N}$ (mg:L-1) & $\mathbf{P}$ ( $\left.\mathbf{m g} \cdot \mathbf{L}^{-1}\right)$ & $\mathbf{K}$ ( $\left.\mathbf{m g} \cdot \mathbf{L}^{-1}\right)$ \\
\hline 2.96 & 0.04 & 2.01
\end{tabular}

Source: averages from Agència Catalana del'Aigua (ACA).

We assumed that intensities of water use by crop type would match on average with those reported in Medios que se utilizan para sumministrar el riego a las tierras y distribución de los cultivos de la zona regable (JCA, 1916). This report quantified irrigation at province level per hectare of crop type. Irrigation, with perhaps the exception of horticultural land, was only "support" irrigation. Water inputs were the minimum doses just to avoid the failure of the crop, e.g. irrigated wheat was watered twice along all the crop lifespan (JCA, 1916). We applied the irrigation doses to the irrigated crop types described in 1922 (JCA, 1923).

\section{RESULTS}

Circa 1860, manure and humanure were the source of more than the half of NPK added to soils (Table 8). Due to the dynamics of the $\mathrm{N}$ cycle, the other fertilizers e.g. hormigueros, biomass buried were more important for $\mathrm{P}$ and $\mathrm{K}$ than for $\mathrm{N}$. Manure and humanure were the source of more than the half only for $\mathrm{K} c .1920$ (Table 9). $\mathrm{N}$ additions due to the $\mathrm{N}$ cycle dynamics were still important (33\%). However, synthetic fertilizers comprised for 10,56 and $20 \%$ of NPK respectively.

Circa 1860 vineyards extracted 37, 40 and 44\% of NPK in harvest respectively, followed by rainfed cereal and legumes with 30,30 and $19 \%$, irrigated cereal and legumes 10,8 and $8 \%$ and horticultural land 3, 5 and $5 \%$ (Figure 3). In the system c. 1920, vineyards extracted 29, 29 and $45 \%$ of NPK in harvest respectively, rainfed cereal and legumes 23,18 and $15 \%$, irrigated cereal and legumes 16,10 and $9 \%$ and horticultural land 14,23 and $14 \%$.

As we discussed in last section, the changes added in the methodology would not modified significantly the results of Tello et al. (2012). Therefore, despite inaccuracies and uncertainties, in both cases the nutrients extracted were almost in equilibrium with the nutrients added. The weakest point of the balance in Sentmenat was $\mathrm{N}$, while $\mathrm{K}$ and $\mathrm{P}$ were almost in equilibrium. Circa 1920 the most unbalanced nutrient was K. 
TABLE 7

Summary of sources used in the NPK balance c. 1920

\begin{tabular}{|c|c|c|c|c|}
\hline \multirow[t]{5}{*}{ Extractions } & \multirow[t]{3}{*}{ Harvest } & \multicolumn{2}{|l|}{ Produce } & JCA (1923) \\
\hline & & \multicolumn{2}{|l|}{ Pruning } & Marco et al. (n. d.) \\
\hline & & \multicolumn{2}{|l|}{ NPK values } & Soroa (1953) \\
\hline & $\mathrm{N}$ emissions & \multicolumn{2}{|l|}{ Manure storage } & Eggleston et al. (2006) \\
\hline & & \multicolumn{2}{|l|}{ Soil management } & Eggleston et al. (2006) \\
\hline \multirow[t]{25}{*}{ Additions } & Synthetic fertilizers & \multirow{2}{*}{\multicolumn{2}{|c|}{$\begin{array}{l}\text { Applied } \\
\text { NPK values }\end{array}$}} & JCA (1921) \\
\hline & & & & $\begin{array}{l}\text { Average values in Aguirre-Andrés } \\
\text { (1971); Gallego (1986); García } \\
\text { Luzón (1922); López-Mateo } \\
\text { (1922); Soroa (1953) }\end{array}$ \\
\hline & Organic non-manure & \multicolumn{2}{|l|}{ Rainfall (Deposition) } & Rodrigo (1998) \\
\hline & & \multicolumn{2}{|l|}{ Free-Fixation } & $\begin{array}{l}\text { García-Ruiz et al. (2012); } \\
\text { Loomis, Connor and Cassman } \\
\text { (2011) }\end{array}$ \\
\hline & & \multirow[t]{4}{*}{ Humanure } & Population settlements & Esteve (2003) \\
\hline & & & Production & Gotaas (1956) \\
\hline & & & Recollection & Garcia-Faria (1889) \\
\hline & & & NPK values & Galán (2015: Annex 4.B) \\
\hline & & \multirow[t]{4}{*}{ Symbiothic N fixation } & Legume crops & JCA (1923) \\
\hline & & & Green manure area & JCA (1921) \\
\hline & & & Green manure NPK values & Average from Soroa (1953) \\
\hline & & & Fix. Factors & García-Ruiz et al. (2012) \\
\hline & & \multirow[t]{2}{*}{ Seeds } & Amount & Soroa (1953) \\
\hline & & & NPK values & Soroa (1953) \\
\hline & & \multirow[t]{3}{*}{ Irrigation } & Irrigated area & $\operatorname{JCA}(1916,1923)$ \\
\hline & & & Water doses & JCA (1916) \\
\hline & & & NPK values & ACA \\
\hline & & \multirow[t]{2}{*}{ Other } & Applied & JCA (1921) \\
\hline & & & NPK values & Galán (2015: Annex 4.B) \\
\hline & \multirow[t]{6}{*}{ Manure } & \multirow[t]{4}{*}{ Manure } & Livestock numbers & MF (1924) \\
\hline & & & Live weights & JCA (1920) \\
\hline & & & Manure production & $\begin{array}{l}\text { Average of values in Cascón } \\
\text { (1918), JCA (1920) and } \\
\text { references included in Marco et } \\
\text { al. (n. d.), Aguilera (1906), JCA } \\
\text { (1892), Loomis, Connor and } \\
\text { Cassman (2011), and Van Slyke } \\
\text { (1932) }\end{array}$ \\
\hline & & & NPK values & $\begin{array}{l}\text { Average of values in Galán } \\
\text { (2015: Annex 4.B) for the } \\
\text { corresponding livestock types in } \\
\text { MF (1924) }\end{array}$ \\
\hline & & \multirow[t]{2}{*}{ Straw } & Beddings & Cascón (1918) \\
\hline & & & NPK values & $\begin{array}{l}\text { Soroa (1953) for the } \\
\text { corresponding leguminous } \\
\text { crops production of JCA (1923) }\end{array}$ \\
\hline
\end{tabular}




\section{TABLE 8}

NPK balance for farmland in Sentmenat c. 1860

\begin{tabular}{|c|c|c|c|}
\hline & $N\left(\mathbf{k g} \cdot \mathbf{h a}^{-1}\right)$ & $P\left(\mathbf{k g} \cdot \mathrm{ha}^{-1}\right)$ & $K\left(\mathbf{k g} \cdot \mathbf{h a}^{-1}\right)$ \\
\hline Rainfall & 0.7 & 0 & 0.9 \\
\hline Free $\mathrm{N}$ fixation & 4.7 & & \\
\hline Symbiotic fixation & 3.0 & & \\
\hline Seeds & 0.5 & 0.1 & 0.1 \\
\hline Manure & 7.5 & 2.4 & 6.6 \\
\hline Human sewage finally applied & 4.3 & 0.8 & 0.9 \\
\hline Other fertilizers & 2.1 & 1.4 & 2.3 \\
\hline ADDITIONS & 22.8 & 4.7 & 10.8 \\
\hline Harvest & 12.5 & 3.7 & 8.9 \\
\hline $\mathrm{N}$ losses due manure storage & 5.8 & 0.1 & 1.3 \\
\hline $\mathrm{N}$ losses due soil management & 5.6 & 0 & 1.3 \\
\hline EXTRACTIONS & 23.9 & 3.8 & 11.5 \\
\hline Balance A-E & -1.1 & 0.9 & -0.7 \\
\hline
\end{tabular}

Source: Tello et al. (2012).

TABLE 9

NPK balance for farmland in Barcelona province $c .1920$

\begin{tabular}{|c|c|c|c|}
\hline & $N\left(\mathbf{k g} \mathbf{h a}^{-1}\right)$ & $P\left(\mathbf{k g} \cdot \mathrm{ha}^{-1}\right)$ & $\mathrm{K}\left(\mathrm{kg} \cdot \mathrm{ha} \mathrm{a}^{-1}\right)$ \\
\hline Rainfall & 5.04 & 0.12 & 0.86 \\
\hline Free $\mathrm{N}$ fixation & 4.00 & & \\
\hline Symbiotic fixation & 12.55 & & \\
\hline Irrigation & 5.76 & 0.09 & 3.90 \\
\hline Seeds & 1.29 & 0.19 & 0.45 \\
\hline Manure & $27.89 \pm 5.12$ & $6.19 \pm 1.38$ & $20.76 \pm 5.87$ \\
\hline Humanure & $1.77 \pm 0.97$ & $0.48 \pm 0.18$ & $0.56 \pm 0.31$ \\
\hline Synthetic fertilizers & 6.68 & 8.83 & 6.50 \\
\hline Other fertilisers & 0.00 & 0.00 & 0.00 \\
\hline ADDITIONS & 64.97 & 15.89 & 33.03 \\
\hline Harvest & 40.54 & 7.98 & 34.36 \\
\hline $\mathrm{N}$ losses due manure storage & $11.56 \pm 2.27$ & & \\
\hline $\mathrm{N}$ losses due soil management & $7.90 \pm 0.13$ & & \\
\hline EXTRACTIONS & 59.99 & 7.98 & 34.36 \\
\hline Balance A-E & 4.98 & 7.91 & -1.34 \\
\hline
\end{tabular}

Source: our own. 


\section{FIGURE 3}

NPK balance of the cropland area of Sentmenat c. 1860 and the province of Barcelona c. 1920
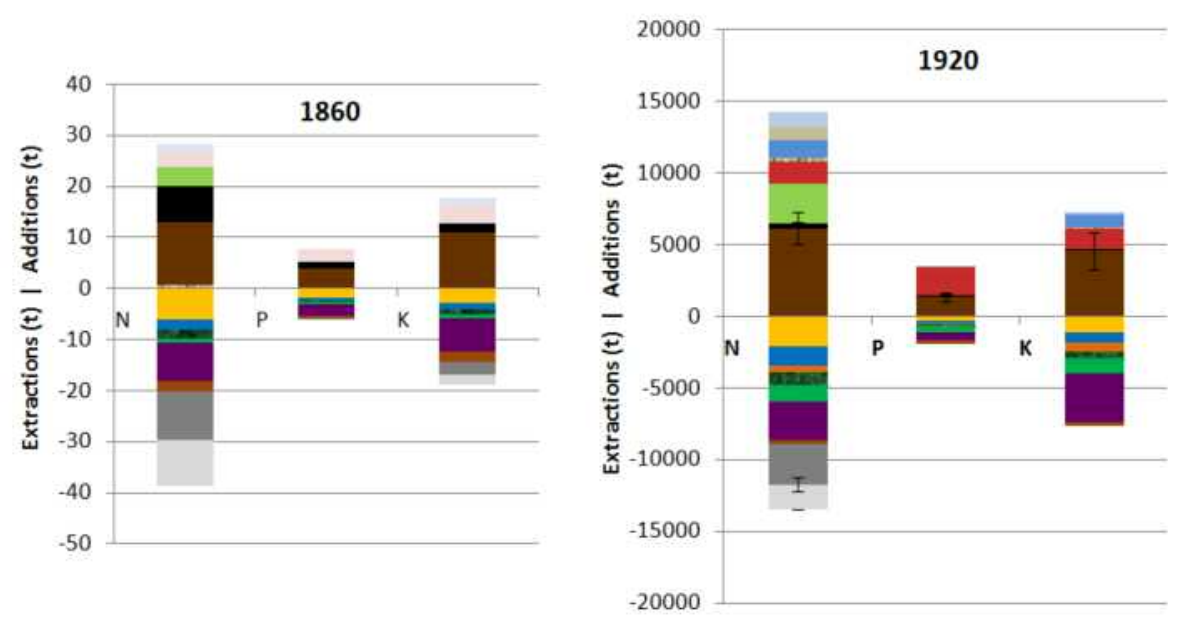

\begin{tabular}{|l|l|l|l|}
\hline & Rainfall & & Other fertilizers \\
\hline & Free N fixation & Symbiotic fixation \\
\hline Irrigation & Humanure & Cereal and leguminous rainfed \\
\hline & Seeds & Harvest & Cereal and leguminous irrigated \\
\hline Synthetic fertilizer & Storage & Roots and bulbs \\
\hline Manure & Management & Forages \\
\hline
\end{tabular}

Source: Tello et al. (2012) and our own as described in text.

The nutrient balance of the cropland area of Sentmenat c. 1860 published in Tello et al. (2012) has been adapted to the legend used here. Note that the two balances are not at the same scale. Negative values represent extractions and losses, positive values are additions of nutrients. Error bars are the accumulation of Standard Deviations in each extraction or addition bar and are due to the estimation of manure, humanure and the $\mathrm{N}$ emissions associated.

\section{DISCUSSION}

As we said in methodology section, due to scale differences we can only compare the balances between c. 1860 and c. 1920 between fertilizer type, composition of harvest and the overall balance. 


\subsection{Type of fertilizer}

The origin of fertilizers strongly differed in both cases. The non-manure organic fertilizers had more weight $c .1860$ than $c .1920$ in the replenishment of all nutrients. Among these non-manure, the main source of $\mathrm{N} c .1860$ was free fixation, while $c .1920$ were leguminous crops consistently with the greater cropland area sown.

There was more manure available $c .1920$ than $c .1860\left(4.57 \pm 0.68 \mathrm{t} \cdot \mathrm{ha}^{-1}\right.$ vis-à-vis 1.4 $\mathrm{t} \cdot \mathrm{ha}^{-1}$ respectively). However, although higher than in Sentmenat, the average in Barcelona province did not reach the manure doses recommended by the agronomists of the time,

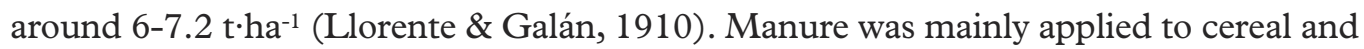
leguminous crops (from the source we cannot distinguish between irrigated or rainfed) and then to horticultural land (JCA, 1921).

The use of humanure per ha is higher in the system $c .1860$ despite lower population densities as less was lost due to the disposal system type, opposite of what happened in the city of Barcelona, where the proximity of the sea and the bad conditions of the sewage systems (García Faria, 1893) allowed less recovering of humanure.

The rest of fertilizers that we grouped as "other" (homigueros, ashes and other materials buried) were higher $c .1860$ than $c .1920$. The reason is that we could not quantify them $c .1920$ as, in contrast to neighbouring provinces, they were neglected by the agronomist in charge of Barcelona (JCA, 1921). These other fertilizers could respond to practices relevant at local level but were diluted at a more aggregated scale. This could explain why the engineers of the Junta Consultiva Agronómica did not consider them. Another possible explanation relies in the intensity of labour of these practices (Tello et al., 2012). The significant rise in agricultural wages experienced between the two dates (Garrabou \& Tello, 2002), together with the peak of deforestation attained during the First World War (Cervera, Garrabou \& Tello, 2015), would have reduced these fertilizing practices (e.g. hormigueros).

Synthetic fertilizers were absent $c .1860$. In Barcelona province the main type used was Superphosphate, which together with potassium sulphate were mainly applied to vines. The rest of synthetic fertilizers were mainly applied to cereal and leguminous crops (from the source we cannot distinguish between irrigated or rainfed), except for slag of iron ores (Escorias Thomas), which were mainly applied to grasslands (JCA, 1921). According to the same source, when compared with its neighbouring provinces, Barcelona had the highest use of this kind of fertilizers, probably due to the commercial port. 


\subsection{Composition of harvest}

In both systems, vineyards and rain-fed cereals extracted the most of the nutrients. However, in the system $c .1920$ irrigated cereals and legumes and horticultural land extract higher share of nutrients than in the system $c .1860$. This is due to the greater area (in horticultural land) and the increase of yields in both due to improvements in the irrigation system and to higher the availability of organic and synthetic fertilizers due to the proximity to Barcelona city as was discussed in the methodology section.

\subsection{The nutrient balance}

The Spanish agronomists at the beginning of the twentieth century knew that to preserve or increase their fertility, it was necessary to refill the nutrients extracted by crops. They, criticised insistently the low livestock densities and the ensuing chronic insufficiency of manure, and recommended the use of other fertilizers (synthetic and organic) as an obligatory complement to manure (Cascón, 1918; García Luzón, 1922; Llorente \& Galán, 1910; Rueda y Marín, 1934). Along with the sellers of P fertilizers (Escorias Thomas, 1897), they argued that although $\mathrm{N}$ was the main concern in agriculture, it was the main nutrient returned by organic fertilizing methods. Therefore, there was a need to complement them with fertilizers rich in other nutrients.

In addition, other agronomists insisted in abandoning the extended belief that permanent wooden crops, such as olive groves or vineyards, did not need fertilization. Besides, they provided other complementary sources of nutrients, cheap and available for farmers, such as human faeces, dry blood, shearing residues, or even the dead and dried bodies of locusts hunted when there was a plague (López-Mateo, 1922; Soroa, 1929). This belief was a heritage from the times when the produce (wine or oil in this case) was just a part of all the extractions (i.e. vegetal covers, pruning) from these wooden crops (González de Molina et al., 2014; Infante-Amate \& González de Molina, 2013). Less intensity of extractions meant that without human driven fertilization the $\mathrm{N}$ balance was compensated by natural entries and $\mathrm{P}$ and $\mathrm{K}$ were removed from the soil reservoirs (González de Molina et al., 2014).

Beyond agronomists considerations, tenants and sharecroppers had to accomplish the contractual obligations of landowners concerning fertility, which started to be common in the second half of the nineteenth century. They could be, for example, the prohibition to sell the straw and the obligation to use it as bedding material for the manure of the farm, 
or the obligation to burn the pruning from vineyards in soil covered piles called hormigueros and use them as fertilizer (Saguer \& Garrabou, 1996).

A key missing point in this study is the amount of fertilizers applied per crop type. We know from other historical studies that there were strong differences. For example, in the South of the Iberian Peninsula fertilizing efforts were concentrated in the lands closest to villages due to transport and labour costs. The faraway olive groves were barely fertilized (González de Molina, 2002; González de Molina \& Guzmán, 2006).

A similar situation could have been happening in the vineyards of our case study, as from qualitative sources we know that they were not fertilized at all c. 1860, a trend that started to be broken from the beginning of the twentieth century with the American breeds. In both balances, the overall nutrients extracted were almost in equilibrium with the nutrients added. The most unbalanced nutrient $c .1920$ was K. Recall that vineyards occupied the half of cropland and extracted more $\mathrm{K}$ than other crops and so had more influence in the $\mathrm{K}$ of the overall balance than other crops. Synthetic fertilizers were used in vineyards according to JCA (1921) but according to the observations of the agronomists above mentioned there were vineyards that were not fertilized. From Sentmenat $c$. 1860 , we know that the smallest landowners ( $<5 \mathrm{ha}$ ) had nearly only vineyards, whereas larger landowners had a combination of rainfed and irrigated grain, vineyards and forest (Garrabou et al., 2010). Only if this land distribution was maintained c. 1920, the poorest smallest farmers, who mainly had vineyards, had not access to sources of fertilizers c. 1920, i.e. market, forest or livestock. Hence, our hypothesis is that c. 1920 largest farmers fertilized their vineyards but smallest did not, and this is reflected in the overall balance. Future research on land ownership and availability of fertilizers is needed to test this hypothesis.

\section{CONCLUSION}

We have improved the methodology to build a balance of soil nutrients in Sentmenat $c$. 1860 of Tello et al. (2012) and applied it to the case of the province of Barcelona c. 1920. These changes included the use of more sources and more justification of some decisions. However, if these changes would be applied to Tello et al. (2012) the results of the overall balance would not change significantly.

In addition, we have discussed the changes in both systems using the information from the nutrients balance. From the data collected c. 1860 in Sentmenat, it was concluded that vineyards were under-fertilized not because there were insufficient organic fertiliz- 
ers but mainly due to the lack of access of many small winegrowers to livestock, pastureland and woodland (Tello et al., 2012), as it can be understood by considering land distribution. We have seen that $c .1920$, harvest and fertilizers added were higher overall due to manure, more leguminous crops but also synthetic fertilizers, which were inexistent $c .1860$.

The main limitation of this study is that we cannot distinguish the application of fertilizers per crop type. However, we guess that the wooden crops owned by smallest farmers without access to sources of fertilizers (i.e. market, forest, livestock) were underfertilized. Relating fertilizer availability, crop types and ownership would bring into light the relation between inequality and fertility.

This attempt of comparing two incomparable cases is more important due to its heuristic value than due to results. We believe that we have solved some pending steps of the nutrient balance from Tello et al. (2012), thus paving the way for future researchers to link Environmental History with socioeconomic factors.

\section{AKNOWLEDGEMENTS}

I am grateful to Enric Tello for fruitful comments and Gael Sentís, Meera Supramanian and three anonymous reviewers from Historia Agraria. This research was supported by the Canadian Social Sciences and Humanities Research Council, Partnership Grant 8952011-1020 and the Spanish MINECO trough FPI grant No. BES-2010-035947.

\section{REFERENCES}

Agència Catalana de l'Aigua (ACA). Xarxes de control del medi. http://aca-web. gencat.cat/sdim/visor.do [Last accessed April 2013].

Agencia Estatal de Meteorología (AEMET). Valores climatológicos normales: Cataluña. http://www.aemet.es/es/serviciosclimaticos/datosclimatologicos/valoresclima tologicos? $\mathrm{k}=\mathrm{cat}$

Aguilera, J. (1906). Teoría y práctica de los abonos. Barcelona: Librería de Francisco Puig. Badia-Miró, M., Tello, E., Valls, F. \& Garrabou, R. (2010). The Grape Phylloxera Plague as a Natural Experiment:The Upkeep ofVineyards in Catalonia (Spain), 18581935. Australian Economic History Review, 50 (1), 39-61. http://doi.org/10.1111/ j.1467-8446.2009.00271.x 
Badia-Miró, M. \& Tello, E. (2014). Vine-Growing in Catalonia:The Main Agricultural Change Underlying the Earliest Industrialization in Mediterranean Europe (17201939). European Review of Economic History, 18 (2), 203-26. http://doi.org/10.1093/ ereh/heu006

BARLES, S. (2007). Feeding the City: Food Consumption and Flow of Nitrogen, Paris, 1801-1914. Science of the Total Environment, 375 (1-3), 48-58.

Billen, G., Garnier, J., Mouchel, J.-M. \& Silvestre, M. (2007a). The Seine System: Introduction to a Multidisciplinary Approach of the Functioning of a Regional River System. Science of the Total Environment, 375 (1-3), 1-12.

Billen, G., Garnier, J., Némery, J., Sebilo, M., Sferratore, A., Barles, S., Benoît, P. \& BENoÎT, M. (2007b). A Long-Term View of Nutrient Transfers through the Seine River Continuum. Science of the Total Environment, 375 (1-3), 80-97.

CAscón, J. (1918). El estiércol y la alimentación animal. Madrid: Imprenta de "Alrededor del Mundo".

Cervera, T., Garrabou, R. \& Tello, E. (2015). Política forestal y evolución de los bosques en Cataluña desde el siglo XIX hasta la actualidad. Investigaciones de Historia Económica-Economic History Research, 11 (2), 116-127.

ChORLEY, G. P. H. (1981). The Agricultural Revolution in Northern Europe, 1750-1880: Nitrogen, Legumes, and Crop Productivity. The Economic History Review, 34 (1), 71 93. http://doi.org/10.1111/j.1468-0289.1981.tb02007.x

Cussó, X., Garrabou, R. \& Tello, E. (2006). Social Metabolism in an Agrarian Region of Catalonia (Spain) in 1860-1870: Flows, Energy Balance and Land Use. Ecological Economics, 58 (1), 49-65.

Eggleston, S., Buendia, L., Mrwa, K., Ngara, T. \& TANabe, K. (Eds.) 2006 IPCC Guidelines for National Greenhouse Gas Inventories. Hayama: Institute for Global Environmental Strategies.

ELLIS, E. \& WANG, S. (1997). Sustainable Traditional Agriculture in the Tai Lake Region of China. Agriculture, Ecosystems $\mathcal{E}$ Environment, (61), 177-193.

EsCORIAS THOMAS (1897). Instrucciones para el empleo de los abonos minerales a base de Escorias Thomas. Valencia: Imprenta de Manuel Alufre.

Esteve, A. (2003). El Nomenclàtor com a font per a l'estudi territorial de la població a Catalunya: Aplicacions, 1857-1998. Doctoral thesis. Barcelona: Universitat Autònoma de Barcelona.

Galán, E. (2015). Socio-Ecological Transition of Organic Agricultures in Catalonia (late $19^{\text {th }}-20^{\text {th }}$ Century). Doctoral thesis. Barcelona: Universitat de Barcelona.

Gallego, D. (1986). Transformaciones técnicas de la agricultura española en el primer tercio del siglo xx. In R. Garrabou, J. Sanz Fernández, C. Barciela \& J. I. JiméNEZ BlANCo (Eds.), Historia agraria de la España contemporánea (pp. 171-223). Barcelona: Crítica. 
García Faria, P. (1893). Proyecto de saneamiento del subsuelo de Barcelona. Tomo I: Memoria descriptiva. Barcelona: Imprenta de Henrich y Comp. en comandita.

García Luzón, M. (1922). Cómo se compra un abono. Madrid: Calpe. (Catecismos del agricultor y del ganadero, 48).

Garcia-Ruiz, R., González de Molina, M., Guzmán, G. I., Soto, D. \& InfanteAmate, J. (2012). Guidelines for Constructing Nitrogen, Phosphorus, and Potassium Balances in Historical Agricultural Systems. Fournal of Sustainable Agriculture, 36 (6), 650-682. http://doi.org/10.1080/10440046.2011.648309

Garrabou, R., Pascual, P., Pujol, J. \& Saguer, E. (1995). Potencialidad productiva y rendimientos cerealícolas en la agricultura catalana contemporánea (1820-1935). Historia Agraria, (10), 89-130.

Garrabou, R., Saguer i Hom, E. \& Planas i Maresma, J. (2001). Un capitalisme imposible?: La gestió de la gran propietat agrària a la Catalunya contemporània. Vic: Eumo.

GaRRABou, R. \& Tello, E. (2002). Salario como coste, salario como ingreso: El precio de los jornales agrícolas en la Cataluña contemporánea, 1727-1930. In J. M. MARTíNEZ-CARRIÓN (Ed.), El nivel de vida en la España rural, siglos XVIII-XX (pp. 113-182). San Vicente del Raspeig: Universidad de Alicante.

Garrabou, R., Tello, E. \& Cussó, X. (2010). Ecological and Socio-Economic functioning in the Middle of the Nineteenth Century: A Catalan Case Study (the Vallès County, 1850-1870). In E. LANDSTEIner \& E. LANGTHALER (Eds.), Agrosystems and Labour Relations in European Rural Societies. (Middle Ages-Twentieth Century) (pp. 119-154). Turnhout: Brepols.

GEHR (1991). Estadísticas históricas de la producción agraria española, 1859-1935. Madrid: Ministerio de Agricultura, Pesca y Alimentación.

GonZÁlez DE Molina, M. (2002). Environmental Constraints on Agricultural Growth in 19th Century Granada (Southern Spain). Ecological Economics, 41 (2), 257-270. González de Molina, M., García Ruiz, R., Guzmán, G., Soto, D. \& InfanteAmate, J. (2010). Guideline for Constructing Nutrient Balance in Historical Agricultural Systems (And its Application to Three Case-Studies in Southern Spain). Sociedad Española de Historia Agraria-Documentos de Trabajo, (10-8).

GonzÁlez de Molina, M. \& GuZmán, G. (2006). Tras los pasos de la insustentabilidad: Agricultura y medio ambiente en perspectiva histórica (siglos XVIII-XX). Barcelona: Icaria.

GonzÁlez de Molina, M., Infante-Amate, J. \& Guzmán, G. (2014). Del manejo tradicional al manejo orgánico del olivar: Aplicaciones prácticas del conocimiento histórico. Revista de Historia, (70), 37-68.

GotaAs, H. B. (1956). Composting: Sanitary Disposal and Reclamation of Organic Wastes. World Health Organization Monograph Series, (31). 
Holland, E. A., Dentener, F. J., Braswell, B. H. \& Sulzman, J. M. (1999). Contemporary and Pre-Industrial Global Reactive Nitrogen Budgets. In A. R. TownSEND (Ed.), New Perspectives on Nitrogen Cycling in the Temperate and Tropical Americas (pp. 7-43). Dordrecht: Springer Netherlands.

Infante-Amate, J. \& GonzÁlez de Molina, M. (2013). The Socio-Ecological Transition on a Crop Scale: The Case of Olive Orchards in Southern Spain (1750-2000). Human Ecology, 41 (6), 961-969.

Instituto Nacional de Estadística (1920). Censo de la población de España. Madrid: Impr. de los hijos de M. G. Hernández.

Jenkins, J. (2005). The Humanure Handbook: A Guide to Composting Human Manure. $3^{\text {rd }}$ ed. Grove City: Jenkins.

Junta Consultiva Agronómica (1892). La ganadería en España: Avance sobre la riqueza pecuaria en 1891. Madrid: Dirección General de Agricultura, Industria y Comercio.

JUNTA CONSUltiva AgRONÓMICA (1916). Medios que se utilizan para sumministrar el riego a las tierras y distribución de los cultivos en la zona regable: Resumen hecho por la funta Consultiva Agronómica de las memorias de 1916 remitidas por los ingenieros del servicio agronómico provincial. Madrid: Impr. de los hijos de M. G. Hernández.

Junta Consultiva Agronómica (1920). Estudio de la ganadería en España: Resumen hecho por la funta Consultiva Agronómica de las memorias de 1917 remitidas por los ingenieros del servicio agronómico provincial. Madrid: Impr. de los hijos de M. G. Hernández.

Junta Consultiva Agronómica (1921). Materias fertilizantes empleadas en la agricultura: Resumen hecho por la funta Consultiva Agronómica de las memorias de 1919 remitidas por los ingenieros del servicio agronómico provincial. Madrid: Impr. de los hijos de M. G. Hernández.

Junta Consultiva Agronómica (1923). Avance estadístico de la producción agrícola en España: Resumen hecho por la funta Consultiva Agronómica de las memorias de 1922 remitidas por los ingenieros del servicio agronómico provincial. Madrid: Impr. de los hijos de M. G. Hernández.

Kimura, S. D. \& Hatano, R. (2007). An Eco-Balance Approach to the Evaluation of Historical Changes in Nitrogen Loads at a Regional Scale. Agricultural Systems, 94 (2), 165-176.

Kimura, S. D., LiAng, L. \& Hatano, R. (2004). Influence of Long-Term Changes in Nitrogen Flows on the Environment: A Case Study of a City in Hokkaido, Japan. Nutrient Cycling in Agroecosystems, 70 (3), 271-282.

KING, F. H. (1911). Farmers of Forty Centuries: Organic Farming in China, Korea, and fapan. Madison: Mrs. F. H. King. 
Lassaletta, L., Billen, G., Romero, E., Garnier, J. \& Aguilera, E. (2013). How Changes in Diet and Trade Patterns have shaped the N Cycle at the National Scale: Spain (1961-2009). Regional Environmental Change, 14 (2), 785-797.

Llorente, A. \& GALÁN, R. (1910). Teoría y práctica de los abonos. Valladolid: J. Montero. Loomis, R. S., Connor, D. J. \& Cassman, K. G. (2011). Crop Ecology: Productivity and Management in Agricultural Systems. $2^{\text {nd }}$ ed. Cambridge: Cambridge University Press.

López-Mateo, R. (1922). Abono del olivo. Madrid: Espasa-Calpe. (Catecismos del agricultor y del ganadero, Serie 4, Agronomía 6).

Marco, I., Padró, R., Galán, E., Tello, E., Olarieta, J. \& Garrabou, R. (n.d.). A Proposal for a Workable Analysis of Energy Return On Investment (EROI) in Agroecosystems. Part II: Accounting for an Empirical Example (the Vallès County, Catalonia, 1860-1999). Social Ecology Working Paper.

Marull, J., Pino, J. \& Tello, E. (2008). The Loss of Landscape Efficiency: An Ecological Analysis of Land-Use Changes in Western Mediterranean Agriculture (Vallès County, Catalonia, 1853-2004). Global Environment, (2), 112-150.

Millán, J., Tello, E. \& Jover, G. (2006). La crisis de coexistència de les formes de propietat: El sentit de la reforma agrària liberal i el referent revolucionari francès. In R. Garrabou (Ed.), Història agrària dels Països Catalans. Segles XIX-XX. Vol. 4. Barcelona: Fundació Catalana per a la Recerca i la Innovació.

Ministerio de Fomento (1924). Censo de la riqueza pecuaria formulado con arreglo a los datos remitidos por los Ingenieros fefes de las Secciones Agronómicas. Madrid: Ministerio de Fomento.

Muro, J. I., NadAl, F. \& Urteaga, L. (1996). Geografía, estadística y catastro en España, 1856-1870. Barcelona: Ediciones del Serbal.

Oenema, O., Kros, H. \& DeVRIES, W. (2003). Approaches and Uncertainties in Nutrient Budgets: Implications for Nutrient Management and Environmental Policies. European fournal of Agronomy, 20 (1-2), 3-16.

PiQueras, J. (2005). La filoxera en españa y su difusión espacial: 1878-1926. Cuadernos de Geografía, (77), 101-136.

Rodrigo, A. (1998). Deposició atmosfèrica en dos alzinars (Quercus ilex L.) del Montseny sotmesos a una exposició contrastada de contaminants de l'àrea barcelonina $i$ vallesana. Doctoral thesis. Barcelona: Universitat Autònoma de Barcelona.

Rueda y Marín, M. M. (1934). Plantaciones y marcos. (Catecismos del agricultor y del ganadero, serie 7, Cultivos arbóreos, 7).

SAGUER, E. \& GARRABOU, R. (1996). Métodos de fertilización en la agricultura catalana durante la segunda mitad del siglo XIx: Una aproximación a los procesos físicos de reposición de la fertilidad agrícola. In J. M. NAREDO \& R. GARRABOU (Eds.), La fertilización en los sistemas agrarios (pp. 89-125). Madrid: Fundación Argentaria. 
SCHNeIDER, M. \& MCMichael, P. (2010). Deepening, and Repairing, the Metabolic Rift. The Fournal of Peasant Studies, 37 (3), 461-84. http://doi.org/10.1080/03066150. 2010.494371

Serra, E. (1988). Pagesos $i$ senyors a la Catalunya del segle XVII: Baronia de Sentmenat 1590-1729. Barcelona: Crítica.

SMIL, V. (2001). Enriching the Earth: Fritz Haber, Carl Bosch, and the Transformation of World Food Production. Cambridge: MIT Press.

SOROA, J. M. DE (1929). Los abonos baratos. (Catecismos del agricultor y del ganadero, serie 4, Agronomía y agricultura general, 1).

SoROA, J. M. DE (1953). Prontuario del agricultor y del ganadero: (agenda agrícola reformada). $8^{\text {th }}$ ed. Madrid: Dossat.

Soto, R. \& BATET, C. (1997). Las donaciones a censo y los establecimientos como estrategia señorial: Patrimonio Sentmenat siglos X-XV. In E. ToRIJANO, L. E. EsPINOZA, J. Infante, A. Bejarano \& R. Robledo (Eds.), VIII Congreso de Historia Agraria: Preactas (pp. 227-244). Salamanca, 28-30 de mayo.

SUDRIÀ, C. (1987). Un factor determinante: La energía. In C. SUDRIÀ, J. NADAL \& A. CARRERAS (Eds.), La economía española en el siglo XX: Una perspectiva histórica (pp. 313364). Barcelona: Ariel.

Tello, E., Garrabou, R., Cussó, X., Olarieta, J. R. \& Galán, E. (2012). Fertilizing Methods and Nutrient Balance at the End of Traditional Organic Agriculture in the Mediterranean Bioregion: Catalonia (Spain) in the 1860s. Human Ecology, 40 (3), 369-383.

Tello, E. \& SudriÀ, C. (Eds.) (2011). El valor geográfico de España (1921):Emilio Huguet delVillar. Barcelona: Universitat de Barcelona.

Van Slyke, L. L. (1932). Fertilizer and Crop Production. New York: Orange Judd. 